\title{
Association Between Oxygen Saturation, Neutrophil- Lymphocyte Ratio and D-dimer With Mortality Based on Clinical Manifestation of COVID-19 Patients
}

\author{
Marwan Marwan, ${ }^{1,2}$ Muhammad Rizqan Khalidi, ${ }^{2,}{ }^{3}$ Siti Khotimah, ${ }^{4}$ Sri

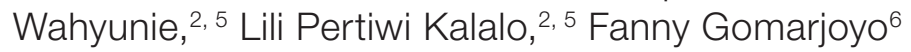

\begin{abstract}
Background / Aim: Coronavirus 2019 (COVID-19) infection is caused by severe acute respiratory syndrome coronavirus type 2 (SARS-CoV-2). It has become an emergency condition for global public health. Oxygen saturation has important role for diagnosing the patient in the hospital. The neutrophil-lymphocyte ratio (NLR) is a marker for the viral inflammatory reaction to confirm the viral or bacterial infection. The D-dimer is also known as biomarker for severity and prognosis of COVID-19. The aim of the study was to investigate the risk factors of mortality in COVID-19 patients based on oxygen saturation, neutrophil-lymphocyte ratio and D-dimer.

Methods: Data has been obtained from confirmed cases of COVID-19 in Abdul Wahab Sjahranie Hospital from October until November 2020. They were collected and analysed with Chi-squared test by SPSS 22.0 software.

Results: There were 60 patients with SARS-CoV-2 infection in this study, 48 (80\%) patients survived and 12 (20\%) deceased. Peripheral oxygen saturation $<90 \%$ had $13(21.7 \%)$ and $\geq 90 \%$ had 47 (78.3\%) patients. There were $13(21.7 \%)$ patients with NLR value $<3.13$ and $\geq 3.1347$ (78.3\%) patients. D-dimer value less than 0.5 had $9(15 \%)$ and $\geq 0.5$ had 51 (85\%) patients. The results of statistical analysis have showed that there were relationship between oxygen saturation $(\mathrm{p}=0.002)$ and survival rate of COVID patients.

Conclusion: According to the research that has been conducted, there was correlation between oxygen saturation and mortality of COVID-19 patient. It could be used as biomarker to improve the management of COVID-19 patients.
\end{abstract}

Key words: Oxygen saturation; Neutrophil lymphocyte ratio; D-dimer; Clinical manifestations of COVID-19.
(1) Pulmonology Division-Laboratory of Internal Medicine, Faculty of Medicine, Mulawarman University, Samarinda, Indonesia.

(2) Abdul Wahab Sjahranie General Hospital, Samarinda, Indonesia.

(3) Laboratory of Anaesthesiology, Faculty of Medicine, Mulawarman University, Samarinda, Indonesia.

(4) Laboratory of Biochemistry, Faculty of Medicine, Mulawarman University, Samarinda, Indonesia

(5) Laboratory of Clinical Pathology, Faculty of Medicine, Mulawarman University, Samarinda, Indonesia.

(6) Faculty of Medicine, Mulawarman University, Samarinda, Indonesia.

Correspondence:

SITI KHOTIMAH

E: st_khotimah@yahoo.com

M: +6281350226175

\section{ARTICLE INFO}

Received: 28 October 2021

Revision received: 4 December 2021 Accepted: 5 December 2021

\section{Introduction}

Coronavirus disease 2019 (COVID-19), was discovered in Wuhan, China, in December 2019. It was caused by the severe acute respiratory syndrome coronavirus 2 (SARS-CoV-2). ${ }^{1}$ Since December 2019 to January 2020, number of cases have increased rapidly, reported of 44 cases. In less than a month, this disease has spread in other countries such as Thailand, Japan and South Korea. This virus could be transmitted from human to human widely. Latest case on 13 August 2020, WHO announced there were 20 million confirmed cases and 737,417 cases people died of COVID-19 
worldwide; while in Indonesia 1,026,954 million cases has been determined with 132,138 confirmed positive cases and 5,968 (4.5\%) cases with lethal outcome. ${ }^{2}$ The pathogenesis of SARSCoV-2 is still unknown. It will infect alveoli with receptors binding and make entrance to cell. Glycoprotein that contained in envelope spike, virus will bind to cellular receptor as Angiotensin-converting enzyme 2 (ACE-2) on SARS-CoV-2. SARS$\mathrm{CoV}-2$ will do duplication of genetic material and synthesising proteins in cells, then it will appear on the surface cell as new virion. ${ }^{3}$

Based on existing data, comorbid disease such as hypertension and diabetic mellitus, as well as male gender, active tobacco smoking are risk factors of SARS-CoV-2 infection. It is caused by ACE2 receptors that increase rapidly. ${ }^{4}$ Others risk factors are having contact, including living in the same household with COVID-19 patient and travel history to affected area. If living in one environment but no contact within two meters radius is also considered as low risk. It has been determined by Centres for Disease Control and Prevention (CDC). ${ }^{5}$ There are asymptomatic, mild, moderate and severe infection that could be found in severe acute respiratory syndrome (SARS) and Middle East respiratory syndrome (MERS). There are several clinical manifestations of this virus including fever, cough and shortness of breath, watery diarrhoea, myalgia, severe lymphopenia, prolonged clotting profiles, heart disease and sudden death. ${ }^{6,7}$ The incidence rate of coronavirus has increased greatly in various countries, so WHO has declared it as pandemic on 30 January $2020 .{ }^{8}$ Statistics has shown $14 \%$ of pneumonia-related COVID-19 cases are severe and $5 \%$ of infected patients require intensive care. ${ }^{9}$

This situation is very high risk nationally as well as globally as long as vaccine implementation is still in progress. In Indonesia, public health emergency management is carried out through quarantine both at the entrance and region. Indonesia has taken policy for making large social restriction, based on epidemiological considerations, the magnitude of threat, effectiveness, resources support, technical operations, political considerations, economics, social and cultural. ${ }^{10}$ Based on the laboratory results, there are biomarkers that could represent inflammation also mortality such as oxygen saturation, neutrophil lymphocyte ratio (NLR) and D-dimer.

\section{Methods}

\section{Design of the study}

This study was cross-sectional observational analytical study of 60 patients that were treated at Abdul Wahab Sjahranie Hospital, Indonesia from October to November 2020.

\section{Study subjects}

These subjects were patients who were under supervision for COVID-19. Inclusion criteria were: (1) confirmed COVID-19 infection based on real time reverse transcriptase polymerase chain reaction (RT-PCR) from throat swab sample; (2) typical symptoms of pneumonia such as fever, cough, shortness of breath, etc; and (3) the severity of pneumonia classified as moderate or severe.

\section{Diagnostic procedures}

The diagnosis of COVID-19 was based on the Coronavirus Disease Prevention and Control Guideline of the Directorate General for Disease Prevention and Control, Indonesia. ${ }^{10}$ All subjects have done blood tests, chest X-rays and PCR swab tests.

\section{Data measurement}

Peripheral oxygen saturation $\left(\mathrm{SpO}_{2}\right)$ was divided into $<90 \%$ and $\geq 90 \%{ }^{10}$ The NLR is systemic inflammatory marker of the infectious disease obtained by dividing the absolute number of neutrophil by the absolute lymphocyte count. The NLR cut-off point of was divided into two groups at $<$ 3.13 and $\geq 3.13$ based on research. ${ }^{11} \mathrm{D}$-dimer value less than $0.5 \mu \mathrm{g} / \mathrm{mL}$ was considered normal. ${ }^{12}$

\section{Statistical analysis}

The data showed normal distribution. Chi-square was used to analyse the association between oxygen saturation, NLR and D-dimer with mortality. P-value $<0.05$ was set as statistically significant. SPSS 22.0 software was used.

\section{Ethical clearance}

Ethical authorisation was obtained from the Health Research Ethics Committee, Abdul Wahab Sjahranie Hospital under No 253/KEPKAWS/X/2020. 


\section{Results}

In this study, medical records from COVID-19 patients at Abdul Wahab Sjahranie Hospital were used.

The total sample were 60 . From this study, 48 (80\%) patients survived and 12 (20\%) deceased.

Table 1: Characteristics and status of patients infected with SARS-CoV-2

\begin{tabular}{lccc}
\hline Gender & $\begin{array}{c}\text { All patients } \\
(\mathbf{n}=\mathbf{6 0})\end{array}$ & $\begin{array}{c}\text { Survived } \\
\mathbf{( n = 4 8 )}\end{array}$ & $\begin{array}{c}\text { Deceased } \\
(\mathbf{n = 1 2})\end{array}$ \\
\hline Male & $38(63.3 \%)$ & $28(65.1 \%)$ & $10(34.9 \%)$ \\
\hline Female & $22(36.6 \%)$ & $17(39.5 \%)$ & $5(60.5 \%)$ \\
\hline
\end{tabular}

$\mathrm{SpO}_{2}<90 \%$ had 13 (21.7\%) and $\geq 90 \%$ had 47 (78.3\%) patients had significance mortality rate based on clinical manifestation $(\mathrm{p}=0.002)$.

Table 2: Oxygen saturation findings of patients infected with SARS-COV-2

\begin{tabular}{lccccc}
\hline $\begin{array}{l}\text { Oxygen } \\
\text { saturation }\end{array}$ & $\begin{array}{c}\text { Deceased } \\
(\mathbf{n}=\mathbf{1 2})\end{array}$ & $\begin{array}{c}\text { Survived } \\
(\mathbf{n}=\mathbf{4 8})\end{array}$ & p value & Mean & $\begin{array}{c}\text { Standard } \\
\text { Deviation }\end{array}$ \\
\hline$<90 \%$ & $7(58.3 \%)$ & $6(12.5 \%)$ & 0.002 & 1.78 & 0.41 \\
\hline$\geq 90 \%$ & $5(41.7 \%)$ & $42(87.5 \%)$ & & & \\
\hline
\end{tabular}

There were 13 (21.7 \%) patients with NLR value $<3.13$ and $\geq 3.1347$ (78.3\%) patients. There was no statistical significance in mortality rate between groups, with $p=0.488(p>0.05 \%)$.

Table 3: Neutrophil-lymphocyte ratio of patients infected with SARS-CoV-2

\begin{tabular}{|c|c|c|c|c|c|}
\hline $\begin{array}{l}\text { Neutrohil } \\
\text {-lymphocyte } \\
\text { ratio }\end{array}$ & $\begin{array}{c}\text { Deceased } \\
(n=12)\end{array}$ & $\begin{array}{l}\text { Survived } \\
(n=48)\end{array}$ & $p$ value & Mean & $\begin{array}{l}\text { Standard } \\
\text { Deviation }\end{array}$ \\
\hline$\geq 3.13$ & $13(30.2 \%)$ & $47(69.8 \%)$ & \multirow{2}{*}{0.488} & \multirow{2}{*}{1.21} & \multirow{2}{*}{0.41} \\
\hline$<3.13$ & $2(16.7 \%)$ & $11(22.9 \%)$ & & & \\
\hline
\end{tabular}

Table 3: D-dimer values of patients infected with SARS-CoV-2

\begin{tabular}{cccccc}
\hline D-dimer & $\begin{array}{c}\text { Deceased } \\
(\mathbf{n}=\mathbf{1 2})\end{array}$ & $\begin{array}{c}\text { Survived } \\
(\mathbf{n}=\mathbf{4 8})\end{array}$ & p value Mean & $\begin{array}{c}\text { Standard } \\
\text { Deviation }\end{array}$ \\
\hline$\geq 0.5$ & $12(100 \%)$ & $39(81.3 \%)$ & 0.113 & 1.15 & 0.36 \\
\hline$<0.5$ & $0(0 \%)$ & $9(18.8 \%)$ & & & \\
\hline
\end{tabular}

The value of D-dimer $\geq 0.5$ was in 51 (85 \%) and $<0.5$ was in $9(15 \%)$ patients. There was no statistical significance in mortality rate between groups, with $p=0.113(p>0.05)$.

\section{Discussion}

Based on the Coronavirus Disease Prevention and Control (COVID-19) Guideline of the General Directorate of Disease Prevention and Control, Indonesia, there are some criteria to categorise COVID-19. First is asymptomatic COVID-19 (patient show no health problem). Second, mild clinical manifestations without complications (patients with non-specific symptoms such as fever, cough and headache). Patients usually recover after one week. The third is a moderate, including symptoms such as mild pneumonia, but no sign of severe pneumonia. Fourth, severe pneumonia (patients with respiratory infection who present with one of symptoms: respiratory rate more than 30 times per minute and oxygen saturation less than $90 \%$ ). Fifth is a critical illness (patients get worst after one week, with manifested acute respiratory distress syndrome - ARDS). ${ }^{10}$

There are 3 criteria of ARDS: mild ARDS if 200 $\mathrm{mmHg}<\mathrm{PaO}_{2} / \mathrm{FiO}_{2} \leq 300 \mathrm{mmHg}$; moderate ARDS if $100 \mathrm{mmHg}<\mathrm{PaO}_{2} / \mathrm{FiO}_{2} \leq 200 \mathrm{mmHg}$ with PEEP $\geq 5 \mathrm{~cm} \mathrm{H}_{2} \mathrm{O}$, or without ventilation; severe ARDS if $\mathrm{PaO}_{2} / \mathrm{FiO}_{2} \leq 100 \mathrm{mmHg}$ with PEEP $\geq 5 \mathrm{cmH}_{2} \mathrm{O}$, or without ventilation. Critical illness could cause septic shock, multi organ failure, including kidney failure or heart failure and death. The patient's final conditions that confirmed as COVID-19 pneumonia indicated that $48(80 \%)$ patients survived and $12(20 \%)$ patients deceased. $\mathrm{SpO}_{2}$ had important role in mortality ratio. It also could be correlated with the final prognosis. ${ }^{10}$

The role of pathogenesis and progression of ACE2 is target receptor for viral entry that can cause hypoxia. There is decrease of amount oxygen level especially in arterial blood. ACE-2 is an enzyme that can attach to the outer surface membrane in several organs, such as lungs, kidney, heart, arteries and intestines. ACE-2 will catalyse the conversion of angiotensin-2 (vasoconstrictor) to angiotensin 1-7 (vasodilator) to protect lung injury. Excessive ACE-2 expression in human will increase the severity of COVID-19 infection. ${ }^{13}$ In human body, ACE-2 has important roles in expressing the surface of pulmonary alveolar epithelial cells and enterocytes in arterial as well as venous endothelial cells. ${ }^{14}$ Another consideration is the phenomenon of hypoxic pulmonary vasoconstriction. Clinical observations of several patients with COVID-19 have infiltrate, endothelitis of pulmonary vasculature and microthrombi 
from pulmonary pathology of COVID-19 that can make airway obstruction, low oxygen level and death. $^{15}$

Neutrophils have a role as one of the human immune cells. When pathogenic microorganism penetrate the body, immune cells will do the defence regulation. ${ }^{16}$ When the body's immunity is compromised, the risk of infection can increase. ${ }^{17}$ Lymphocytes are one of leukocyte cell that have function in an immune system. Lymphocyte help to defence and protect body from bacterial and viral infection. If the lymphocyte level decreases (lymphopenia), it could make the infection become worse. ${ }^{18}$

Neutrophil lymphocyte ratio (NLR) is one of the parameters to look in prognosis of infection and inflammation. Increased NLR indicates a poor clinical prognosis. ${ }^{19}$ It may be related to the cytokine release storm that can change clinical condition from moderate to severe clinical manifestations. If there is a new virus with no memory in the immune system and also has high patho- genicity, it tends to release cytokines out of control which activate more white blood cell. There is also research that that state that NLR is not related to the mortality rate. Therefore, it could be used as an early warning signal and important step to give treatment for COVID-19 patients. ${ }^{20}$

D-dimer is a fibrin degradation product occurring as a result of the fibrinolysis process. D-dimer is a blood test used to detect parts of thrombus in blood stream. Higher D-dimer concentrations could be produced by a blood clot. In this research, D-dimer value greater than 0.5 $\mu \mathrm{g} / \mathrm{mL}$ were found, which caused the endothelial cell dysfunction. It impacts severity grade of COVID-19 patients. ${ }^{21} \mathrm{D}$-dimer also related to hypoxia. Hypoxia associated with COVID-19 could cause vasoconstriction and low blood flow that contribute to epithelial injury and cause microthrombosis. ${ }^{22}$ Patients with severe cases are usually older and have underlying conditions, which were risk factors of hypercoagulation or thrombosis. ${ }^{23}$

\section{Conclusion}

COVID-19 can cause hypoxaemia as result of damage to the lungs from inflammatory reactions to the viral infection of the respiratory tract. The NLR and D-dimer have been the most promising predictors of moderate-severe incidence from COVID-19 pneumonia. An early diagnose will be beneficial to patient classification management.

\section{Acknowledgements}

None.

\section{Conflict of interest}

None.

\section{References}

1. Coronavirus disease (COVID-19) Situation Report-128. [Internet]. Available from: https://www.who.int/emergencies/diseases/novel-coronavirus-2019/situation-reports. [Cited: 24-Dec-2020].

2. Wu Z, McGoogan JM. Characteristics of and important lessons from the coronavirus disease 2019 (COVID-19) outbreak in China: summary of a report of 72314 cases from the Chinese Center for Disease Control and Prevention. JAMA 2020 Apr 7;323(13):1239-42.

3. Kementerian Kesehatan RI. Pedoman Pencegahan dan Pengendalian CORONAVIRUS DISEASE (COVID-19). [Internet]. Available from: https://covid19.go.id/p/ protokol/pedoman-pencegahan-dan-pengendalian-coronavirus-disease-covid-19-revisi-ke-5. [Cited: 24-Dec-2020]. Indonesian.
4. Shenoy N, Luchtel R, Gulani P. Considerations for target oxygen saturation in COVID-19 patients: are we under-shooting? BMC Med 2020;18:260. doi.org/10.1186/ s12916-020-01735-2.

5. Mercier J, Voutsadakis IA. The platelets-neutrophils to lymphocytes ratio: a new prognostic marker in metastatic colorectal cancer. J Gastrointest Oncol 2018 Jun;9(3):478-86.

6. Channappanavar R, Perlman S. Pathogenic human coronavirus infections: causes and consequences of cytokine storm and immunopathology. Semin Immunopathol 2017 Jul;39(5):529-39.

7. Hess K, Grant PJ. Inflammation and thrombosis in diabetes. Thromb Haemost 2011 May;105 Suppl 1:S43-54.

8. Kemenkes RI. Pedoman Pencegahan dan Pengendalian 
Coronavirus Disease (COVID-19) Revisi ke-4. [Internet]. Available from: https://infeksiemerging.kemkes.go.id/ download/REV-04_Pedoman_P2_COVID-19_27_Maret2020_TTD1.pdf. [Cited: 24-Dec-2020]. Indonesian.

9. Susilo A, Rumende CM, Pitoyo CW, Santoso WD, Yulianti M, Herikurniawan, et al. [Coronavirus disease 2019: review of current literature]. J Penyakit Dalam Indones 2020;7(1):45-67. Indonesian.

10. Centers for Disease Control and Prevention. Interim US guidance for risk assessment and public health management of persons with potential coronavirus disease 2019 (COVID-19) exposures: geographic risk and contacts of laboratory-confirmed cases. [Internet]. Available from: https://www.cdc.gov/coronavirus/2019-ncov/php/ risk-assessment.html. [Cited: 24-Dec-2020].

11. Fuad M, Oehadian A, Prihatni D, Marthoenis. Neutrophil-to-Lymphocyte Ratio and Covid-19 symptom-based severity at admission. AMJ 2021;8(1):1-6.

12. Dashraath P, Wong JLJ, Lim MXK, Lim LM, Li S, Biswas A, et al. Coronavirus disease 2019 (COVID-19) pandemic and pregnancy. Am J Obstet Gynecol 2020 Jun;222(6):521-31.

13. de Wit E, van Doremalen N, Falzarano D, Munster VJ. SARS and MERS: recent insights into emerging coronaviruses. Nat Rev Microbiol 2016 Aug;14(8):523-34.

14. Chen N, Zhou M, Dong X, Qu J, Gong F, Han Y, et al. Epidemiological and clinical characteristics of 99 cases of 2019 novel coronavirus pneumonia in Wuhan, China: a descriptive study. Lancet 2020 Feb 15;395(10223):50713.

15. Huang C, Wang Y, LiX, Ren L, Zhao J, Hu Y, etal. Clinical features of patients infected with 2019 novel coronavirus in Wuhan, China. Lancet 2020 Feb 15;395(10223):497506.

16. Liu J, Liu Y, Xiang P, Pu L, Xiong H, Li C, et al. Neutrophil-to-lymphocyte ratio predicts critical illness patients with 2019 coronavirus disease in the early stage.
J Transl Med 2020 May 20;18(1):206. doi: 10.1186/ s12967-020-02374-0.

17. Yu HH, Qin C, Chen M, Wang W, Tian DS. D-dimer level is associated with the severity of COVID-19. Thromb Res 2020 Nov;195:219-25.

18. Gu H, Xie Z, Li T, Zhang S, Lai C, Zhu P, et al. Angiotensin-converting enzyme 2 inhibits lung injury induced by respiratory syncytial virus. Sci Rep 2016 Jan 27;6:19840. doi: 10.1038/srep19840.

19. Hamming I, Timens W, Bulthuis ML, Lely AT, Navis G, van Goor H. Tissue distribution of ACE2 protein, the functional receptor for SARS coronavirus. A first step in understanding SARS pathogenesis. J Pathol 2004 Jun;203(2):631-7.

20. Yeo AJ, Henningham A, Fantino E, Galbraith S, Krause L, Wainwright CE, et al. Increased susceptibility of airway epithelial cells from ataxia-telangiectasia to S. pneumoniae infection due to oxidative damage and impaired innate immunity. Sci Rep 2019 Feb 22;9(1):2627. doi: 10.1038/s41598-019-38901-3.

21. Yang AP, Liu JP, Tao WQ, Li HM. The diagnostic and predictive role of NLR, d-NLR and PLR in COVID-19 patients. Int Immunopharmacol 2020 Jul;84:106504. doi: 10.1016/j.intimp.2020.106504.

22. Soylu K, Gedikli O, Eksi A, Avcioglu Y, Soylu AI, Yuksel $\mathrm{S}$, et al. Neutrophil-to-lymphocyte ratio for the assessment of hospital mortality in patients with acute pulmonary embolism. Arch Med Sci 2016;12(1):95-100.

23. Wong JP, Viswanathan S, Wang M, Sun LQ, Clark GC, D'Elia RV. Current and future developments in the treatment of virus-induced hypercytokinemia. Future Med Chem 2017 Feb;9(2):169-78.

24. Tang N, Bai H, Chen X, Gong J, Li D, Sun Z. Anticoagulant treatment is associated with decreased mortality in severe coronavirus disease 2019 patients with coagulopathy. J Thromb Haemost 2020 May;18(5):1094-9. 